\title{
The use of Teflon as a dural substitute and its other neurosurgical applications
}

\author{
PAUL TENG AND CHRISTOS PAPATHEODOROU \\ From the Neurosurgical Service, Department of Surgery, Kaiser Foundation Hospitals, \\ and Southern California Permanent Medical Group, Los Angeles
}

\begin{abstract}
During the last seven decades many materials have been experimentally tried as dural substitutes, and many have been discarded after being clinically introduced. In recent years, satisfactory results from Orlan (Huertas, 1955), Vinyon 'N' (Teng and Feigin, 1955; Teng, 1961), and homologous dura mater (Crawford, 1957; Campbell, Bassett, and Robertson, 1958) as dural substitutes have been reported. Vinyon ' $\mathrm{N}$ ' has been out of production because it is of no commercial value. It is replaced commercially by Tefion. The present communication concerns the introduction of Teflon cloth as a dural substitute and its other neurosurgical applications. It has been clinically tried during the last two and a half years at the Kaiser Foundation Hospitals of Southern California.
\end{abstract}

\section{THE TEFLON}

The Teflon cloth $^{1}$ is woven in the form of China silk. It is soft, flexible, and dark brown in colour (unbleached). It has a smooth, waxy, and nonadherent surface. In sterilization for medical use, it withstands heat, wet or dry, $350^{\circ}$ to $400^{\circ} \mathrm{F}$., undamaged. It has been repeatedly autoclaved at $270^{\circ} \mathrm{F}$. under $30 \mathrm{lb}$. for five to 10 minutes without any noticeable alteration of its properties. It is well known in the field of cardiovascular surgery, in which braided Teflon tubes are extensively used as aortic and arterial replacements. In this respect, the fine pores of the Teflon do not hinder its use as dural substitute when waterproofing is desirable.

Possible industrial hazards caused by Teflon have been discussed by Tepper (1962). When Teflon burns it generates poisonous fumes. However, this is unlikely to happen in an operating room where open flame is not allowed. Teflon is not inflammable and it has a high melting point. The use of an electrical cautery in the neurosurgical wound would not kindle it.

${ }^{1}$ Teflon cloth bought from Stern and Stern Texile Co., New York, New York.

\section{CLINICAL OBSERVATIONS}

From November 1959 to August 1962 Teflon cloth was used in 36 neurosurgical cases. In 31 patients it $\vec{\circ}$ was used as dural substitute (for cerebral dural $\rightarrow$ defect in 25 , cerebellar dural defect in three, and $\vec{\omega}$ spinal dural defect in three). In four infants Teflon was utilized as bone lining in craniectomy for craniostenosis. In one patient after neurolysis of the left common peroneal nerve in severe cicatrization it was used as a nerve wrap. The time of observation is in these 36 cases varied from two to 33 month $\vec{B}+\vec{A}$ (Table I).

AS CEREBral DURAL SUBSTITUTe Teflon cloth was used to cover cerebral dural defects in 25 cases (ip cluding three metastatic carcinomas, one metastat $\vec{\bullet}$ melanoma, two cerebral lacerations), and in fou after clipping an aneurysm of the anterior conmunicating or internal carotid artery. In these four cases the frontal dural flap was not closed at the end of the operation but loosely replaced over a strip of Teflon cloth, which was used to bridge the gap. In five cases of meningioma, one epidermoid, and $\triangle$ nine gliomas, the dural flap was discarded and re- $\overline{0}$ placed by Teflon cloth. In each instance, the Teflon cloth was tucked under the edge of the dura in order to prevent meningo-cerebral adhesions often noted through the suture line in edge-to-edge anastomosis. No ill-effect has been observed in this group. The longest period of observation was 33 months.

In five cases the Teflon cloth was recovered 123,3 $140,152,223$, and 251 days respectively after being 8 placed in position. The first specimen was lost and four were examined microscopically. At necropsy, 음 dense fibrous tissues were noted on the outer surface of the Teflon cloth. The edge of the incised dura was buried in the scar and firmly adherent to the outer surface of the Teflon. The under surface of the $\sigma$ Tefion cloth was free of adhesions. It was easily $N$ lifted off the cerebral cortex, including the area of N్ biopsy or the area of the transcortical incision 
TABLE I

TEFLON CLOTH RESIDENT IN TISSUE

\begin{tabular}{ll}
$\begin{array}{ll}\text { Case } \\
\text { No. }\end{array}$ & Manner of Utilization \\
\hline 1 & $\begin{array}{l}\text { Substitute for cerebral } \\
\text { dura }\end{array}$ \\
2 &
\end{tabular}

Diagnosis and Site of Teflon Used
Cerebral laceration, R. temporal
Cerebral laceration, L. frontal

(1)

\begin{tabular}{ll}
$\begin{array}{l}\text { Date of } \\
\text { Operation }\end{array}$ & $\begin{array}{l}\text { Size of } \\
\text { Teflon (in.) }\end{array}$ \\
\hline $1 / 6 / 60$ & $2 \times 2$ \\
$1 / 6 / 60$ & $2 \times 2$
\end{tabular}

\begin{tabular}{|c|c|c|}
\hline 3 & & Metastatic carcinoma, R. parietal \\
\hline 4 & & Metastatic carcinoma, R. temporal \\
\hline 5 & & Meningioma, L. pterion \\
\hline 6 & & Malignant meningioma, $\mathbf{R}$. fronto-parasagitta \\
\hline 7 & & Metastatic carcinoma, R. temporal \\
\hline 8 & & Metastatic melanoma, L. temporo-parietal \\
\hline 9 & & Meningioma, L. pterion \\
\hline 10 & & Meningioma, $\mathbf{R}$. frontal parasagittal \\
\hline 11 & & Meningioma, L. posterior frontal parasagittal \\
\hline 12 & & Epidermoid, dura involved L. frontal \\
\hline 13 & & Glioblastoma multiforme, R. posterior frontal \\
\hline 14 & & Glioblastoma multiforme, L. parietal \\
\hline 15 & & Glioblastoma multiforme, L. temporal \\
\hline 16 & $\begin{array}{l}\text { Substitute for cerebral } \\
\text { dura }\end{array}$ & Astrocytoma, L. fronto-temporal \\
\hline 17 & & Glioblastoma multiforme, temporal \\
\hline 18 & & Glioblastoma multiforme, L. temporal \\
\hline 19 & & Glioblastoma multiforme, L. parietal \\
\hline 20 & & Glioblastoma multiforme, L. temporal \\
\hline 21 & & Glioblastoma multiforme, L. temporo-parietal \\
\hline 22 & & $\begin{array}{l}\text { Aneurysm, anterior communication artery, } \\
\text { bifrontal bone flap; clipping of aneurysm }\end{array}$ \\
\hline 23 & & $\begin{array}{l}\text { Aneurysm, anterior cerebral artery, clipping, } \\
\text { R. frontal flap }\end{array}$ \\
\hline 24 & & $\begin{array}{l}\text { Aneurysm, anterior communicating artery, } \\
\text { clipping, R. frontal flap }\end{array}$ \\
\hline 25 & & $\begin{array}{l}\text { Aneurysm, internal carotid artery, clipping, } \\
\text { R. frontal flap }\end{array}$ \\
\hline 26 & $\begin{array}{l}\text { Substitute for cere- } \\
\text { bellar dura }\end{array}$ & $\begin{array}{l}\text { Arnold-Chiari anomaly, posterior fossa- } \\
\text { spinal decompression }\end{array}$ \\
\hline $\begin{array}{l}27 \\
28\end{array}$ & & Pearly tumour, R. petrous \\
\hline 29 & $\begin{array}{l}\text { Substitute for spinal } \\
\text { dura }\end{array}$ & $\begin{array}{l}\text { Meningioma, } R \text {. posterıor tossa } \\
\text { Glioma, intramedullary, C2-C6 }\end{array}$ \\
\hline 30 & & Meningioma, D8-D9 \\
\hline 31 & & Vascular anomaly, D3-D9 \\
\hline 32 & $\begin{array}{l}\text { Bone lining in } \\
\text { craniostenosis }\end{array}$ & $\begin{array}{l}\text { Synostosis, sagittal suture, R. parasagittal } \\
\text { craniectomy }\end{array}$ \\
\hline 33 & & $\begin{array}{l}\text { Synostosis, sagittal suture, R. parasagittal } \\
\text { craniectomy }\end{array}$ \\
\hline 34 & & $\begin{array}{l}\text { Synostosis, sagittal suture, R. parasagittal } \\
\text { craniectomy }\end{array}$ \\
\hline 35 & & $\begin{array}{l}\text { Synostosis, sagittal suture, R. parasagittal } \\
\text { craniectomy }\end{array}$ \\
\hline 36 & Peripheral & $\begin{array}{l}\text { L. common peroneal nerve, cicatrization; } \\
\text { neurolysis }\end{array}$ \\
\hline
\end{tabular}

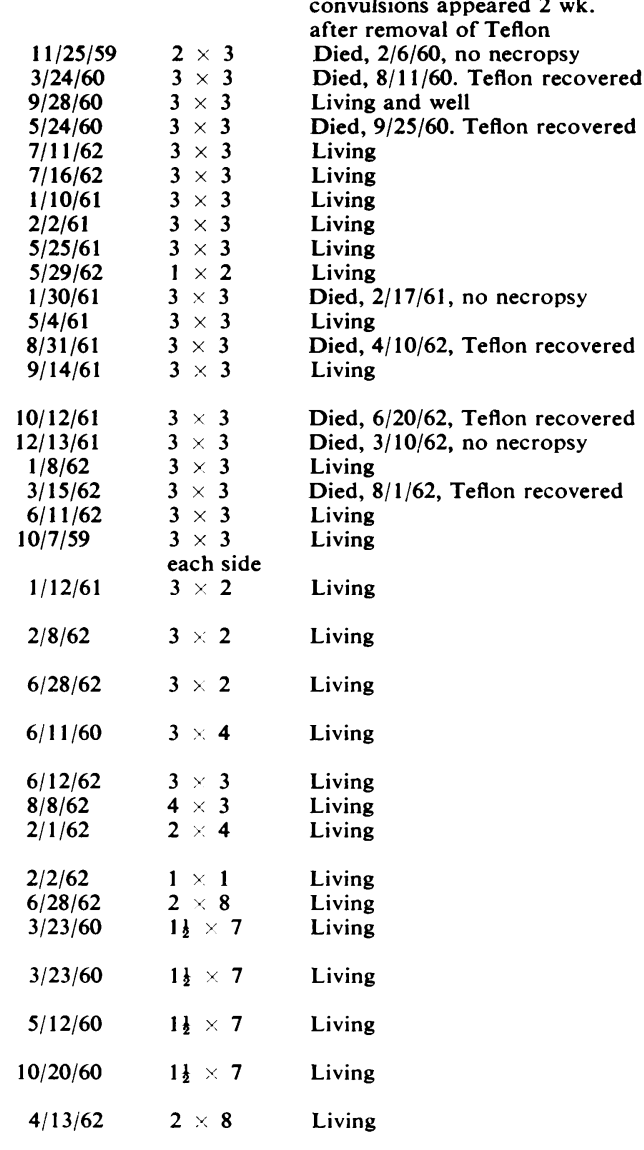

through which the tumour had been partially removed. Gliosis at the operative site was obvious but there was no adhesion to the under surface of the Teflon in all five cases. The cortical vessels appeared normal. They too did not adhere to the cloth. The pia throughout the area covered by the cloth was neither thickened nor changed in colour in comparison with the same region of the opposite hemisphere not clothed with Teflon. Microscopic examination found occasional lymphocytes lodged between the meshes of the Teflon fibres, but there was no foreign body giant cell. The underlying cortex displayed no noticeable change. Figures 1, 2, and 3 are specimens removed from one patient 251 days after the Teflon cloth was placed over the frontotemporo-parietal region of the left hemisphere. The lack of both gross and microscopic reaction is obvious.

AS CEREBELLAR DURAL SUBSTITUTE In three cases Teflon cloth was used to cover the dural defect created by a posterior fossa craniectomy. In all three cases the dura was left open. One operation was for the removal of a right posterior fossa meningioma and one for a partial removal of a petrous epidermoid tumour. The third case was for 


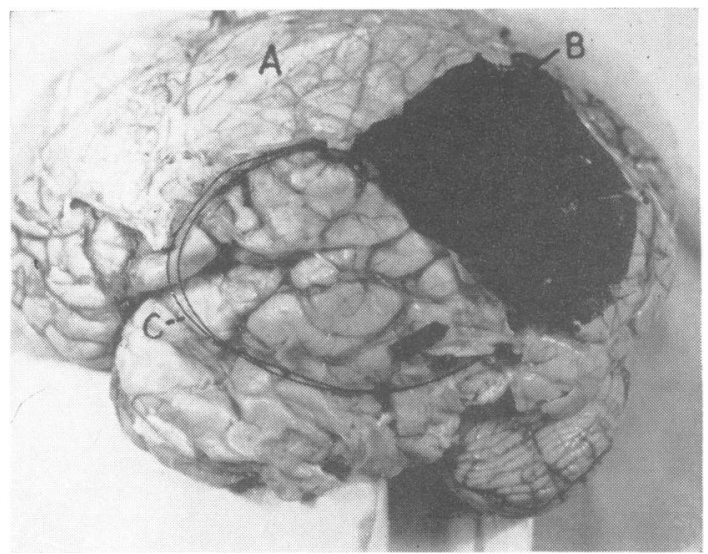

FIG. 1. Case 17. Teflon cloth (black patch), intracranial, resident 251 days as dural substitute.

A Natural dura mater

B Reflected dural substitute, Teflon cloth

C Black silk outlines area covered by Teflon.

Arrow indicates area of gliosis following biopsy.

Note that the leptomeninges are thin and transparent. Normal configuration of cortical vessels and absence of adhesion including area of gliosis.

decompression of an Arnold-Chiari anomaly with obstruction at the craniospinal junction. The third patient, who was operated upon 27 months ago, is illustrated in the following:

This 36-year-old housewife was operated upon on 11 June 1960. An Arnold-Chiari anomaly was exposed through a posterior fossa craniectomy and $\mathrm{Cl}-3$ laminectomy. The cerebellar tonsils extended to $\mathrm{C} 2$ and the medulla was 'hunchback' in appearance. The cerebello-spinal dura was left open. The gap was tented with a piece of Teflon

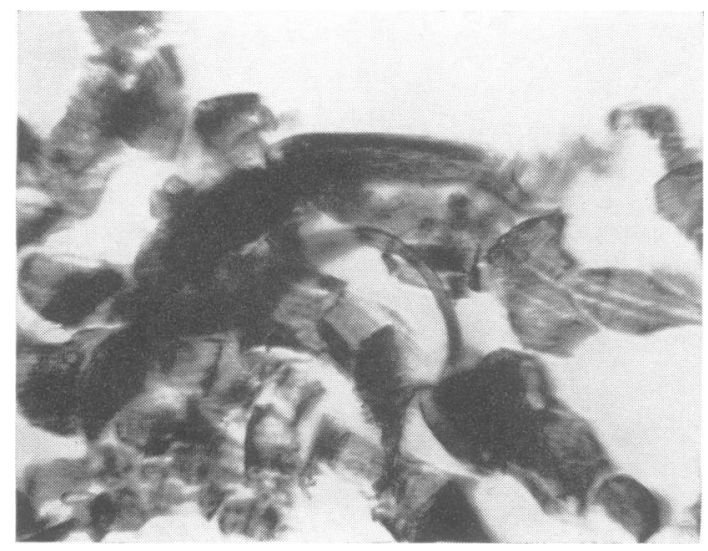

FIG. 3. Specimen from the same case. Magnification of $A_{1}$ of Fig. $2 \times 250$. Cross-section of Teflon cloth fibres. Note the absence of cellular reaction. cloth. Up to date, 27 months after surgery, the patient has been asymptomatic and leading a normal life. The $\mathbb{D}$ Teflon cloth has not produced any untoward effect.

AS SPINAL DURAL SUBSTITUTE The Teflon cloth was $\frac{\bar{c}}{0}$ used to cover spinal dural defects in three cases, $D$ one to cover an extensive vascular anomaly of the dorsal spinal cord and one after the removal of a meningioma from D8, two to seven months ago,
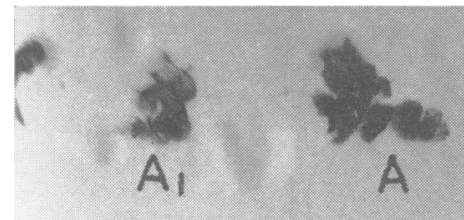

FIG. 2. Same case. $\times 100$

A Teflon cloth fibres

B Pia mater

C Cortex of left temporal lobe.

Note the lack of tissue reactions and normal appearance of the pia mater and cerebral cortex.

respectively. In the former case, the large coils of abnormal vessels herniated through the incised dura, which was left open with its gap covered by Teflon. In the third case, an intramedullary glioma involving the cord from $\mathrm{C} 2$ to $\mathrm{C} 7$ was biopsied and decompressed by leaving the dura open and covering with Teflon. Up to the time of preparation of this article, eight months have elapsed since surgery, and the patient is still able to work as a clerk at a store for electrical supplies. He walks without a cane but his left hand is weak in skilful manoeuvres. No untoward effect appears to have been caused by Teflon in these three cases. 
AS BONE LINING IN CRANIOSTENOSIS AFTER CRANIECTOMY In four infants with premature closure of the sagittal suture, Teflon cloth was used as bone lining after craniectomy to prevent reunion of the bone edges. These cases were followed 23 to 30 months. No ill effect has been caused by Teflon.

AS NERVE WRAP IN CICATRIZATION. In one case, the left common peroneal nerve was involved in severe cicatrization following chronic osteomyelitis for three years as a result of a compound fracture. For the relief of pain, the nerve was dissected free from the surrounding dense scar tissue and wrapped with Teflon cloth. Since the operation five months ago the patient has been free of pain. During the previous two years, three operations for neurolysis were performed, and invariably pain recurred three to five weeks after each attempt.

\section{DISCUSSION}

It is generally believed that the meningo-cerebral adhesions that follow injury or surgery are responsible for the post-traumatic or post-operative convulsive disorders. The purpose of using a dural substitute is to prevent adhesions and cross-circulations between the exposed brain and the overlying soft tissues rather than to fill the defect in the severed dura mater.

A dural substitute must possess specific qualities: it must not be toxic, it must be inert in tissues, not absorbent, resistant to disintegration, of a favourable tensile strength, of a soft consistency, easy to manipulate for wrapping over the surface of the brain, of adequate supply, and easy to sterilize.

The present study indicates that Teflon cloth is chemically inert and not irritating. It has produced no untoward effect in the clinical test. It has remained in tissues for periods of from two to 33 months in $\mathbf{3 6}$ patients. A comparative study of the properties, resources, and method of sterilization of Orlan, homologous dura mater, and Teflon is presented in Table II.

Albin, D'Agostino, White, and Grindlay (1962) reported their observation on bleached Teflon coated with methyl 2-cyanoacrylate. They found in their experimental animals that a fibrous membrane had formed on both surfaces of the coated Teflon cloth used as dural substitute. This has not been observed in our cases, in which the unbleached and uncoated Teflon was used.

Its use in craniostenosis, for the prevention of bone reunion after craniectomy, has also shown satisfactory results. It is soft and easy to use for lining the bone incision.

One of the aims of neurolysis is to prevent recurrence of compression by regrowth of scar tissue along the course of the dissected nerve, and it has often been a problem to find a healthy soft tissue bed for transplantation of the nerve after neurolysis in cases of severe and extensive cicatrization. In such instances, Teflon cloth provides a satisfactory wrap to protect the nerve from the constricting scars.

\section{SUMMARY}

Teflon cloth, a synthetic fabric, has been used as a satisfactory dural substitute, nerve wrap, and bone lining in craniostenosis after craniectomy in 36 cases. The periods of observation ranged from two to 33 months.

Teflon cloth is chemically inert, heat resistant, and is not toxic. It is not absorbed and has a tensile

TABLE II

A COMPARISON OF VARIOUS DURAL SUBSTITUTES RECENTLY USED OR TESTED

\begin{tabular}{|c|c|c|c|c|c|c|}
\hline & Source & Structure & Durability & Flexibility & Tissue Reaction & $\begin{array}{l}\text { Method of } \\
\text { Sterilization }\end{array}$ \\
\hline $\begin{array}{l}\text { Polyethelene } \\
\text { (Ingraham et al., } \\
\text { 1947) }\end{array}$ & $\begin{array}{l}\text { Synthetic } \\
\text { product }\end{array}$ & $\begin{array}{l}\text { Non-porous } \\
\text { sheet }\end{array}$ & Non-absorbable & Flexible & $\begin{array}{l}\text { Thin fibrous capsule } \\
\text { formation; minimal } \\
\text { cellular reaction }\end{array}$ & $\begin{array}{l}\text { Soaking in Zephiran } \\
1: 1,000 \text { solution }\end{array}$ \\
\hline Orlon & $\begin{array}{l}\text { Synthetic } \\
\text { product }\end{array}$ & Cloth & Non-absorbable & Silk-like & $\begin{array}{l}\text { No capsule formation; } \\
\text { minimal cellular re- } \\
\text { action; no foreign } \\
\text { body giant cells }\end{array}$ & Autoclave \\
\hline $\begin{array}{l}\text { Vinyon ' } N \text { ' (out } \\
\text { of production) }\end{array}$ & $\begin{array}{l}\text { Synthetic } \\
\text { product }\end{array}$ & Cloth & Non-absorbable & Silk-like & $\begin{array}{l}\text { No capsule formation: } \\
\text { cellular reaction includ- } \\
\text { ing few foreign body } \\
\text { giant cells }\end{array}$ & Boiling in water \\
\hline $\begin{array}{l}\text { Homologous } \\
\text { dura mater }\end{array}$ & Human body & $\begin{array}{l}\text { Dehydrated } \\
\text { dura }\end{array}$ & $\begin{array}{l}\text { Partially absorbed, } \\
\text { replaced by } \\
\text { fibrous tissues }\end{array}$ & Less flexible & $\begin{array}{l}\text { Minimal cellular re- } \\
\text { action; no foreign } \\
\text { body giant cell; re- } \\
\text { placed by fibrous tissues }\end{array}$ & $\begin{array}{l}\text { Ethylene oxide } \\
\text { immersion; freeze- } \\
\text { drying }\end{array}$ \\
\hline Teflon & $\begin{array}{l}\text { Synthetic } \\
\text { product }\end{array}$ & Cloth & Non-absorbable & Silk-like & $\begin{array}{l}\text { No capsule formation; } \\
\text { minimal cellular re- } \\
\text { action; no foreign body } \\
\text { giant cell }\end{array}$ & Autoclave \\
\hline
\end{tabular}


strength as silk. It can be sterilized by autoclave and it is in abundant supply. It causes negligible tissue reactions.

\section{REFERENCES}

Albin, M. S., D'Agostino, A. N., White, R. J., and Grindlay, J. H. (1962). J. Neurosurg., 19, 545.
Campbell, J. B., Bassett, C. A. L., and Robertson, J. W. (1958). Ibid., 15, 207.

Crawford, H. (1957). Plast, reconstr. Surg., 19, 299.

Huertas, J. (1955). J. Neurosurg., 12, 550.

Ingraham, F. D., Alexander, E. Jr., and Matson, D. D. (1947). J. Amer. med. Ass., 135, 82.

Teng, P., and Feigin, I. (1955). J. Neurosurg., 12, 591

- (1961). J. Neurol. Neurosurg. Psychiat., 24, 182.

Tepper, L. B. (1962). New Eng. J. Med., 267, 349. 